\title{
The relationship between intellectual capital information and firms' market value: a study from an emerging economy
}

\author{
A.A. Ousama, Mashael Thaar Al-Mutairi and A.H. Fatima
}

\begin{abstract}
Purpose - The purpose of this paper is to investigate the relationship between the intellectual capital (IC) information reported in the annual reports and market value of the companies listed on the Qatar Stock Exchange.
\end{abstract}

Design/methodology/approach - The study is based on a panel data collected from the annual reports and Bloomberg database for six years, specifically the periods 2010-2012 and 2016-2018. The total sample consists of 252 observations. The theoretical framework was developed in reference to the resource-based theory. The regression model is based on Ohlson's model, which has been modified by including IC information.

Findings - The study found that there is a significant relationship between IC information and firm market value. This finding indicates that companies report their IC to help the stakeholders (e.g. shareholders, investors) to understand the real value of the company (which includes IC values).

Practical implications - The shift to a knowledge-based economy (KBE) has made knowledge a driver for economic growth, and it has become more important than capital, land and labour. This shift makes IC and resources vital for companies to create wealth, value and gain competitive advantage. The State of Qatar plans to transform its economy to a KBE in its "Qatar Vision 2030". The findings of the study show that the companies have started to depend more on IC to contribute to transforming Qatar's economy to a $K B E$.

Originality/value - This study could be considered a pioneer study to examine the association of IC disclosure and firm value in Qatar. Furthermore, prior literature has mixed findings, which justifies further investigation of IC's effect on market value, particularly in the emerging economy of Qatar.

Keywords Information, Market value, Relationship emerging economies, Intellectual capital

Paper type Research paper

\section{Introduction}

Knowledge has gained prominence and is replacing traditional resources of physical assets and natural resources as the main resource of companies (Drucker, 1992). According to Powell and Snellman (2004), in a knowledge-based economy (KBE), production and services depend on knowledge-intensive activities and support technical and scientific advancement. Therefore, the main component of a knowledge economy is dependence on intellectual capabilities, captured in intellectual capital (IC), rather than on physical inputs or natural resources (Powell and Snellman, 2004).

Although there is no single definition of $\mathrm{IC}$ in the literature, many studies tend to describe it from a value and wealth creation perspective (Stewart, 2000; Ousama and Fatima, 2012). IC consists of a set of non-financial (e.g. human capital, knowledge) and non-physical (e.g. intellectual property, experience) resources that are able to create value and generate wealth (García-Meca and Martínez, 2005; Viedma Marti, 2007); however, the intangible resources are
A.A. Ousama is based at the Department of Accounting and Information Systems, Qatar University, Doha, Qatar.

Mashael Thaar Al-Mutairi is based at the Finance Unit, Institute of Banking Studies, Kuwait City, Kuwait. A.H. Fatima is based at the Department of Accounting, Kulliyyah of Economics and Management Sciences, International Islamic University Malaysia, Kuala Lumpur, Malaysia.

Received 2 January 2019 Revised 18 June 2019 Accepted 21 August 2019

(C) A.A. Ousama, Mashael Thaar Al-Mutairi and A.H. Fatima. Published by Emerald Publishing Limited. This article is published under the Creative Commons Attribution (CC BY 4.0) licence. Anyone may reproduce, distribute, translate and create derivative works of this article (for both commercial and non-commercial purposes), subject to full attribution to the original publication and authors. The full terms of this licence may be seen at http:// creativecommons.org/licences/ by/4.0/legalcode 
not captured by the current accounting system (Abeysekera and Guthrie, 2005; Alfraih, 2017). Therefore, IC is the intangible capital and resources owned or controlled by companies, which can be used to create firm value (Ousama et al., 2011a, Ousama and Fatima, 2012). IC is categorised into three main categories; internal capital (INC), which is the IC inside the organisation, other than the employees; external capital that are outside the company and human capital (Ousama et al., 2011a, Ousama and Fatima, 2012).

As the business world becomes even more globally competitive, companies are turning towards IC as a vital resource (García-Meca, 2005; García-Meca and Martínez, 2007) in optimising their performance and gain competitive advantage (Ousama et al., 2011a; Ousama et al., 2011b; Huang et al., 2013). However, in order for IC in companies to be further translated into firm value, these resources should be disclosed to stakeholders. Therefore, IC disclosure has gradually become widespread globally (Abeysekera and Guthrie, 2004).

Even though IC reporting is practiced by companies in many countries, there is insufficient IC disclosure and the information may lack relevance. Information, in this context, has a major position (Lev, 1992, 2001) because good reporting translates into positive public perception. Consequently, information is disclosed either to focus on the profits earned or expected to be earned (Clarkson et al., 1992; Jog and McConomy, 2003) as generated from the effective utilisation of IC. Therefore, users of the accounting information perceive IC information as useful and relevant for decision-making purposes (Ousama et al., 2011a; Abu Ghaida et al., 2016). This indicates that the market reacts to the reported IC information as it affects firm value.

Prior studies concluded that there is a positive relationship between disclosure and market value (Bruggen et al., 2009; Gordon et al., 2010; Cormier et al., 2011; Uyar and Kiliç, 2012). IC studies proved a similar positive association between IC information and firm market value (Abdolmohammadi, 2005; Ousama et al., 2011b; Abeysekera, 2011). This relationship is derived from the fact that IC forms part of a company's capital and resources. Such information disclosure in the annual reports notifies stakeholders and investors on the financial performance and position of the company. This information will be manifested in the market value of that company, as reflected in share price. Therefore, the objective of this study is to test the relationship between IC information disclosed in the annual reports and the market value of the listed companies in Qatar Stock Exchange (QSE).

The Qatari economy reported the highest GDP growth of 11.9 per cent, on average, over the 2005-2015 periods among all Gulf Cooperation Council (GCC) countries (International Monterey Fund - IMF, 2016). The GCC countries realised that there is a need to diversify their economies and not to depend solely on gas and oil. Therefore, Qatar has developed its Qatar National Vision (QNV) 2030 which aims to shift the economy towards a KBE (Qatar National Vision - QNV, 2008). The QNV 2030 rests on the pillars of human development, social development, economic development and environmental development. The economic development aims to establish "a competitive and diversified economy capable of meeting the needs of, and securing a high standard of living for, its entire people both for the present and for the future" (Qatar National Vision - QNV, 2008). Qatar expects to have sustainable development and a high standard of living by 2030 (Qatar National Vision QNV, 2008). The capital market is expected to play a significant role in the economic development and the transition towards a KBE. The QSE started its operations with less than 20 listed companies and now has grown to 48 listed companies (Qatar Stock Exchange - QSE, 2013, 2019). The QSE continues to attract more local and foreign investors. This could be achieved by having more transparent disclosure, including that of IC information.

This can be considered a pioneering study in Qatar that tests the relationship between the IC information and market value of listed companies. It is hoped that the findings of the 
current study will add value to the existing literature in supporting the impact of IC information on firms' market value. The findings have practical implications for companies and other stakeholders, especially shareholders and investors. The Qatari listed companies will be able to evaluate their current IC disclosure and whether they disclose sufficient and relevant IC information that positivity affects their market value. Also, the shareholders and investors will be able to use such information when assessing the real value of the company (which includes IC values) which would influence the market value positively. Findings indicate that IC disclosure is indeed value relevant would have policy implications for the Qatari authorities. These findings would support Qatari companies having more IC disclosure, as well as be in line with Qatar's transition towards becoming a KBE.

\section{Literature review}

The argument that IC is important in investment decisions has proven that the difference between the book value of a company and its market value is derived mainly from its IC. It is difficult to measure IC by focusing on physical capital and ignoring the intangible capital of the company (Kaplan and Norton, 2001; Ittner et al., 2003; Kennerley et al., 2003). This was a major challenge for the traditional accounting measures that have not yet developed an agreed and reliable measure for IC. Consequently, it has resulted in a gap in information. The current financial reporting model only includes information on some IC components, such as goodwill, R\&D, copyrights, patents and trademarks and continues to ignore the other major IC components. Therefore, such reports have lost their importance as they fail to provide a comprehensive picture of the company, thus can no longer satisfy the shareholders, investors and other users' needs for information. Lack of information on key resources of a company would surely result in an inaccurate evaluation of firm value by the financial market. Therefore, major efforts have been exerted to resolve this problem and to enable companies to produce recognisable IC to improve assessment of firm valuation. As a result, many companies have started to include information about their IC within their annual reports or by providing a separate IC report.

IC studies tried to highlight the importance of IC information for users in their decisions. For example, Mavrinac and Siesfeld (1997) and Bornemann et al. (1999) found that the information on market share, innovativeness and the company's ability to attract and retain talented employees is the most useful to users. On the contrary, Miller (1999) found that the most relevant information is leadership skills, employee satisfaction and employee motivation and their experience. Whereas, Ousama and Fatima (2012) found that information about management philosophy, innovations, shareholders, market value, employee capacities and abilities is most useful for users' decision-making purposes. Similarly, Abu Ghaida et al. (2016) found information about management philosophy, loyal customer and shareholders, as well as market value to be more relevant to the users. Therefore, companies have to apply a more inclusive approach to IC disclosure as this information is value relevant for decision-making purposes (Ousama et al., 2011a; Abu Ghaida et al., 2016).

There are a number of empirical studies in different countries that focus on the relationship between IC information and market value. For example, in the USA (Abdolmohammadi, 2005), Britain, Australia, Hong Kong, Singapore (Vafaei et al., 2011), Sri Lanka (Abeysekera, 2011), Malaysia (Ousama et al., 2011b; Taliyang et al., 2014), German (Gamerschlag, 2013), New Zealand (Ellis and Seng, 2015), ASEAN countries (Nimtrakoon, 2015), Pakistan (Dashti et al., 2016) and Kuwait (Alfraih, 2017). These studies found a positive significant relationship between IC information and market value, consequently providing empirical evidence on the value relevance of IC information. Nevertheless, there were some studies that found no significant relationship between these two variables, such as in Greece (Maditinos et al., 2011) and Italy (Ferraro and Veltri, 2011). The inconsistent results may be due to the fact that Maditinos et al.'s (2011) study was concerned with IC efficiency, 
measured by value-added IC model, instead of IC disclosure. On the contrary, Ferraro and Veltri (2011) argued that the insignificant relationship could be due to the lack of the existence of a recognised and validated framework to measure IC value and disclosure; hence, a more comprehensive and effective measurement for IC information needs to be applied.

The review of the literature above reveals mixed findings. Hence, there is a need for further investigation on the effect of IC information on firm value, especially in developing and emerging economies such as Qatar. This is because, to date, there is a dearth of literature on this issue in Qatar. This motivates and justifies the current study to be conducted to fill the gap in the literature.

\section{Hypothesis development and research method}

\subsection{Development of hypotheses}

According to the resource-based theory, companies use their capital and resources to create value and increase wealth. As mentioned earlier, IC is one of these resources; hence, it plays a significant role in the value creation process (Mouritsen et al., 2004; Ousama et al., 2011b). Based on this view, companies are expected to report IC information to different user groups, including shareholders and investors; subsequently, this information is reflected in the market value (Ousama et al., 2011b). In addition, the empirical research findings supported the significant relationship between IC and firm value. As mentioned earlier, the study investigates the impact of IC information on the market value of the listed companies in QSE. A research framework (Figure 1) was formalised considering that IC information (independent variable) will affect market value (dependent variable). Based on this research framework and the findings of prior IC studies, the following hypotheses were developed.

H1. There is a significant positive relationship between IC information $(I C I)$ and market value of Qatari listed companies.

H2. There is a significant positive relationship between INC information and market value of Qatari listed companies.

H3. There is a significant positive relationship between external capital information (EXCI) and market value of Qatari listed companies.

Figure 1 Theoretical framework




H4. There is a significant positive relationship between human capital information ( $\mathrm{HUCl})$ and market value of Qatari listed companies.

\subsection{Research method}

All listed companies on the QSE for the year 2010 were selected except for Mesaieed Petrochemical Holding Company because it is was established in 2013. The study selected two periods; where the first period consists of the years 2010, 2011 and 2012; and the second period comprises the years 2016, 2017 and 2018. There was a gap of three years between the two periods based on the expectation that IC disclosure will improve over the period from 2010 until 2018. Therefore, the sample consists of 42 companies per year with total panel data of 252 companies for the six years. The selection of all listed companies in QSE is to ensure that this study will reflect the reality because the number of listed companies is considered small compared to other stock markets. Another factor for selecting all the companies listed in QSE is because all their annual reports are available on the QSE website; thus, it is easy to obtain all the required data. The decision to select the first period (i.e. years 2010, 2011 and 2012) was made because IC was a new concept both internationally and in Qatar. Therefore, the listed companies on the QSE may not have been familiar with the IC concept because it is a developing market and few listed companies pay attention to IC disclosure. In the past few years, however, Qatar started to flourish economically and to expand its investment which is reflected in its market. This growth factored into the selection of the second period (years 2016, 2017, and 2018). In addition, the second period represents the most recent data.

\subsection{Data collection}

Secondary resources were used to collect the data needed to achieve the objective of the study. The data were obtained from the Bloomberg database and the annual reports of the companies for the selected years. The data were divided into dependent variable (i.e. firm market value), independent variables (i.e. extent of IC information) and control variables (i.e. book value, net profit, firm size, financial leverage and dividends per share).

\subsection{Variables measurement}

The measurements of the dependent, independent and control variables are explained as follows:

- Firm market value (FMV) was calculated by multiplying share price by the number of its outstanding shares (Ibrahim et al., 2004; Ousama et al., 2011b). The data were obtained from Bloomberg and market data were at three months after the end of a reporting year.

- The extent of IC information (EICl) was measured based on a disclosure index that was adopted from Ousama and Fatima (2012). The index contains a list of $101 \mathrm{IC}$ items that are divided into three categories (i.e. 35 items for $\mathrm{INCl}, 35$ items for $\mathrm{EXCl}$ and 36 items for $\mathrm{HUCl}$ ). A dichotomous scoring system was used in scoring the items in the index; 1 is scored if the item is disclosed in the annual report, whereas 0 is scored if the item is not disclosed. Hence, the $\mathrm{EICl}$ is calculated as follows:

$$
E I C l j=\frac{T I C I S j}{T I C I I j}
$$

where the TICIS $j$ is the total actual IC information score for a company $j$ and $\mathrm{TICIIj}$ is the total IC information items (i.e. 101 items) for a company $j$. Similarly, the extent of IC information for respective INCl (EINCl), EXCl (EEXCl) and $\mathrm{HUCl}(\mathrm{EHUCl})$ was calculated. 
- Book value per share (BVPS) was calculated by dividing total equity (total liabilities deducted from total assets) by its outstanding ordinary shares.

- Net profit (NETPROFT) was measured by the net profit of the year.

- Firm size (SIZE) was measured by the total assets of a company at the end of a reporting year.

- Financial leverage (LEVERAGE) was calculated as a ratio by dividing total liabilities by shareholders' equity.

- Dividend per share (DPS) was the total dividends paid out over an entire year divided by the number of outstanding ordinary shares.

\subsection{Regression model}

A regression model was used to examine the relationship between IC information and firms' market value. The model is a simple modification of Ohlson's (1995) model, with the inclusion of $\mathrm{EICl}$. The model is specified as follows:

$$
\begin{gathered}
\text { FMVjt }+1=\alpha+\beta_{1} \text { EICl } j t+\beta_{2} \text { BVPS } j t+\beta_{3} \text { NETPROFT } j t+\beta_{4} \text { SIZE } j t+\beta_{5} \text { LEVERAGE } j t \\
+\beta_{6} \text { DPS } j t+\text { e } j t
\end{gathered}
$$

The models for the IC categories are as follows:

$$
\begin{aligned}
\text { FMV jt }+1= & \alpha+\beta_{1} \text { EINCI } j t+\beta_{2} \text { BVPS } j t+\beta_{3} \text { NETPROFT } j t+\beta_{4} \text { SIZE } j t \\
& +\beta_{5} \text { LEVERAGE } j t+\beta_{6} \text { DPS } j t+\text { e } j t \\
\text { FMV jt }+1= & \alpha+\beta_{1} \text { EEXCl } j t+\beta_{2} \text { BVPS } j t+\beta_{3} \text { NETPROFT } j t+\beta_{4} \text { SIZE } j t \\
& +\beta_{5} \text { LEVERAGE } j t+\beta_{6} \text { DPS } j t+\text { e } j t \\
\text { FMV } j t+1= & \alpha+\beta_{1} \text { EHUCl } j t+\beta_{2} \text { BVPS } j t+\beta_{3} \text { NETPROFT } j t+\beta_{4} \text { SIZE } j t \\
& +\beta_{5} \text { LEVERAGE } j t+\beta_{6} \text { DPS } j t+\text { ejt }
\end{aligned}
$$

where:

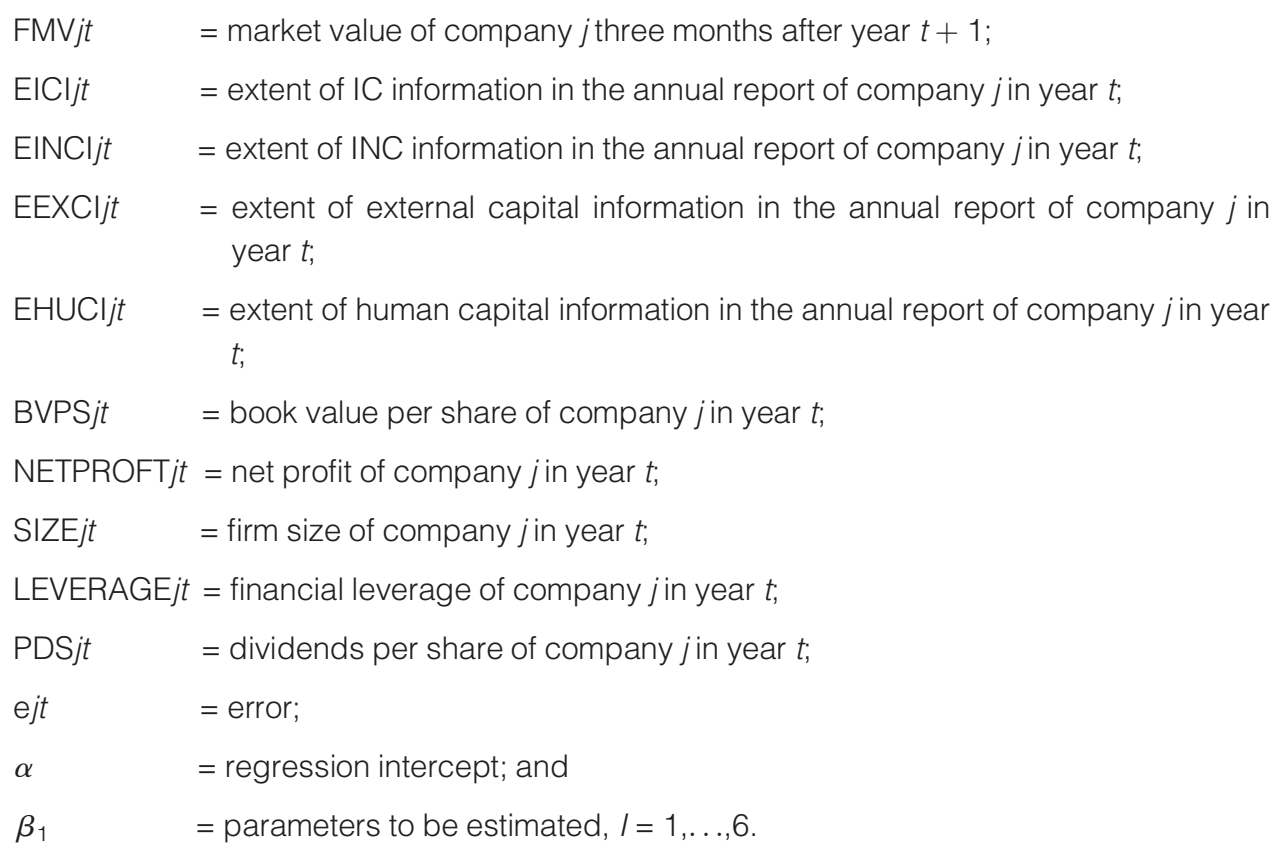




\section{Results and discussion}

The following section presents the results of the descriptive analysis, correlation analysis and regression analysis.

\subsection{Descriptive statistics results}

The descriptive analysis results are presented in Tables 1 and 2. Table I shows the extent of IC information disclosed in the annual reports of the Qatari listed companies in the two periods (2010-2012 and 2016-2018). The mean of $\mathrm{EICl}$ is 0.414 , which indicates that the listed companies disclosed around 41 per cent of their IC information. In addition, the average minimum IC information is 28 per cent and the maximum is 56 per cent. The extent of disclosure of IC information in Qatar is higher compared to previous studies (Whiting and Miller (2008) in New Zealand; Ousama and Fatima (2012) in Malaysia) and lower than others (Bozzolan et al. (2003) in Italy; Wang et al. (2016) in China and India). The implication of this finding is that the listed companies in Qatar generally are aware of the importance of IC in the creation of their firm values; hence, they try to communicate this fact through the disclosure of IC information. The disclosed information can be considered useful from the users' perspective (e.g. shareholders, investors) to evaluate company's market value, as IC plays a significant role in the value creation process.

In addition, Table II shows that the means of EINCI, EEXCI and EHUCI are 0.396, 0.575 and 0.295 , respectively. This indicates that the highest disclosure is for external capital followed by internal and human capitals. Based on the sample, the Qatari listed companies prefer to disclose more information relating to their external capital and less relating to human capital. This could be due to the fact that external IC information is related to the IC outside the company, whereas human capital information is on IC inside the company, which might be considered as a competitive disadvantage if they disclose more information about it.

Table II shows the descriptive statistics for the dependent, independent and control variables. The results of the mean and median indicate the normality of the data.

\subsection{Correlation analysis and results}

Pearson correlation analysis was conducted to test the initial relationship between IC information and market value. Table III presents the results of the correlation analysis. The result does not show a significant correlation between EICl and FMV. Nevertheless, the

\section{Table I Descriptive statistics for $\mathrm{EICl}$ and its categories}

\begin{tabular}{lcccc} 
Measurements & $\mathrm{EICl}$ & $\mathrm{EINCl}$ & $\mathrm{EEXCl}$ & $\mathrm{EHUCl}$ \\
\hline Mean & 0.414 & 0.396 & 0.575 & 0.295 \\
Median & 0.426 & 0.361 & 0.633 & 0.286 \\
Std. Deviation & 0.057 & 0.102 & 0.165 & 0.081 \\
Minimum & 0.277 & 0.194 & 0.200 & 0.143 \\
Maximum & 0.555 & 0.611 & 0.833 & 0.486
\end{tabular}

Table II Descriptive statistics for dependent, independent and control variables

\begin{tabular}{lcccccc} 
Measurements & FMV & BVPS & NETPROFT & SIZE & LEVERAGE & DPS \\
\hline Mean & 9.571 & 1.389 & 8.418 & 8.393 & 0.8225 & 0.241 \\
Median & 9.708 & 1.380 & 8.627 & 8.468 & 0.786 & 0.301 \\
Std. deviation & 0.717 & 0.349 & 0.864 & 1.576 & 0.604 & 0.471
\end{tabular}


Table III Correlation analysis results

\begin{tabular}{|c|c|c|c|c|c|c|c|c|c|}
\hline Variables & 1 & 2 & 3 & 4 & 5 & 6 & 7 & 8 & 9 \\
\hline 1 & 1 & & & & & & & & \\
\hline 2 & 0.057 & 1 & & & & & & & \\
\hline 3 & 0.016 & -0.091 & 1 & & & & & & \\
\hline 4 & 0.061 & $0.648^{* *}$ & $-0.509^{* *}$ & 1 & & & & & \\
\hline 5 & 0.027 & $0.670^{* *}$ & $-0.583^{* *}$ & $0.637^{* *}$ & 1 & & & & \\
\hline 6 & $0.586^{* *}$ & 0.067 & -0.121 & $0.145^{*}$ & 0.046 & 1 & & & \\
\hline 7 & $0.895^{* *}$ & 0.038 & 0.016 & 0.032 & 0.003 & $0.700^{* *}$ & 1 & & \\
\hline 8 & $0.360^{* *}$ & $-0.488^{* *}$ & $0.575^{* *}$ & $-0.656^{* *}$ & $-0.587^{* *}$ & $0.212^{* *}$ & $0.401^{* *}$ & 1 & \\
\hline 9 & $0.263^{* *}$ & $0.388^{* *}$ & $-0.565^{* *}$ & $0.559^{* *}$ & $0.538^{* *}$ & $0.227^{* *}$ & $0.182^{* *}$ & $-0.355^{* *}$ & 1 \\
\hline 10 & $0.268^{* *}$ & -0.091 & 0.036 & -0.099 & -0.053 & $0.430^{* *}$ & $0.353^{* *}$ & 0.110 & -0.119 \\
\hline
\end{tabular}

Notes: **Significant at the 0.01 level; *Significant at the 0.05 level. 1: FMV, 2: EICI, 3: EINCI, 4: EEXCI, 5:EHUCI, 6:BVPS, 7:NETPROFT, 8:SIZE, 9:LEVERAGE, 10:DPS

relationship will be mainly tested by the regression analysis. On the contrary, the table shows that FMV is statistically correlated with all the control variables, i.e. BVPS, NETPROFT, SIZE, LEVERAGE and DPS. In addition, the Pearson correlation analysis was conducted to test the problem of multicollinearity between the independent variables. The coefficients results are less than 0.80 which indicates that the problem of multicollinearity does not exist.

\subsection{Regression analysis and results}

Regression analysis was performed on the panel data for the 2010-2012 and 2016-2018 periods. Table IV reports the results of the impact of IC information on firms' market value of the listed companies in the QSE. The results show that there is a significant positive relationship between $\mathrm{EICl}$ and $\mathrm{FMV}$. In addition, the table shows that $\mathrm{EINCI}, \mathrm{EEXCl}$ and EHUCl are statistically significant in determining FMV. Therefore, $\mathrm{H}_{1}, \mathrm{H}_{2}, \mathrm{H}_{3}$ and $\mathrm{H}_{4}$ are supported. The results are consistent with most prior studies (Abdolmohammadi, 2005; Abeysekera, 2011; Ousama et al., 2011b; Taliyang et al., 2014; Dashti et al., 2016; Alfraih, 2017). This finding indicates that IC information positively affects the market value of the listed companies in Qatar. Therefore, it can be considered that IC information is value relevant in the Qatari context. Consequently, the Qatari listed companies should be motivated to disclose more IC information as it leads to greater company's value by the market. Additionally, it indicates that users (e.g. shareholders, investors) consider the disclosure of IC information as being relevant, hence resulting in higher market value. This might signify a reduction in the information gap between the company and its stakeholders.

\section{Table IV Regression results of the effects of ICI on the FMV}

\begin{tabular}{lrrrrr} 
Variables & Unstandardised coefficients & & \\
& $B$ & Std. error & Standardised coefficients B & $T$ & Sig. \\
\hline (Constant) & -0.082 & 0.259 & & -0.316 & 0.752 \\
EICl & 68.925 & 19.887 & 4.012 & 3.466 & $0.001^{* *}$ \\
EINCl & 24.494 & 7.071 & 2.540 & 3.464 & $0.001^{* *}$ \\
EEXCl & 20.392 & 5.936 & 3.415 & 3.435 & $0.001^{* *}$ \\
EHUCl & 24.256 & 6.925 & 2.006 & 3.503 & $0.001^{* *}$ \\
BVPS & -0.089 & 0.041 & -0.089 & -2.154 & $0.032^{*}$ \\
NETPROFT & 0.896 & 0.043 & 0.896 & 20.729 & $0.000^{* *}$ \\
SIZE & 0.097 & 0.053 & 0.097 & 1.841 & 0.067 \\
LEVERAGE & 0.122 & 0.038 & 0.122 & 3.193 & $0.002^{* *}$ \\
DPS & 0.008 & 0.032 & 0.007 & 0.234 & 0.815 \\
YEAR & 0.029 & 0.029 & 0.051 & 1.030 & 0.304 \\
Notes: $F=117.112$, Sig. & $=0.000$, Adj. $R^{2}=0.822,{ }^{* *}$ Significant at the 0.01 level; * Significant at the \\
O.05 level & & & & &
\end{tabular}


Overall, the findings provide support on the progression of the transformation of the Qatari economy to a KBE as targeted in the QNV 2030. This is indicated by the listed companies starting to depend more on IC resources and then disclosing information about them.

In addition, Table IV shows the results of the relationship between firm market value and control variables. The results show that only book value per share, net profit and leverage had strong significant relationships (at 0.01 and 0.05 level) and firm size had a weak significant relationship (at 0.10 level) with the firm market value, whereas dividends per share had not.

\subsection{Additional analyses and results}

The study conducted additional tests by separating the two sample periods. Tables 5 and 6 show the descriptive statistics for the first period (i.e. 2010-2012) and second period (i.e. 2016-2018), respectively. The results reveal that the means of the extent of IC information are 0.382 for the first period and 0.447 for the second period, respectively. The results indicate that the disclosure of the IC information has increased over the period from 2010 to 2018. In addition, the results showed that the means of internal and human capitals information have increased from 0.440 to 0.710 and from 0.236 to 0.355 , respectively. On the contrary, the mean of INC information has decreased from 0.476 to 0.316 .

Additionally, the study conducted independent sample $t$-tests to examine the significant differences in the disclosure of IC information between the two periods. Table VII shows the results which indicate that the disclosure of IC information was significantly different between the two periods. The finding supports the descriptive

\section{Table V Descriptive statistics for the ICl and its categories (2010-2012)}

\begin{tabular}{lcccc} 
Measurements & $\mathrm{EICl}$ & $\mathrm{EINCl}$ & $\mathrm{EEXCl}$ & $\mathrm{EHUCl}$ \\
\hline Mean & 0.382 & 0.476 & 0.440 & 0.236 \\
Median & 0.396 & 0.500 & 0.433 & 0.229 \\
Std. deviation & 0.060 & 0.073 & 0.124 & 0.043 \\
Minimum & 0.277 & 0.278 & 0.200 & 0.143 \\
Maximum & 0.535 & 0.611 & 0.633 & 0.371
\end{tabular}

\section{Table VI Descriptive statistics for the ICI and its categories (2016-2018)}

\begin{tabular}{lcccc} 
Measurements & $\mathrm{EICl}$ & $\mathrm{EINCl}$ & $\mathrm{EEXCl}$ & $\mathrm{EHUCl}$ \\
\hline Mean & 0.447 & 0.316 & 0.710 & 0.355 \\
Median & 0.446 & 0.306 & 0.700 & 0.343 \\
Std. deviation & 0.030 & 0.050 & 0.047 & 0.066 \\
Minimum & 0.376 & 0.194 & 0.600 & 0.229 \\
Maximum & 0.554 & 0.444 & 0.833 & 0.486
\end{tabular}

Table VII Independent samples test of the ICI (2010-2012 and 2016-2018)

\begin{tabular}{|c|c|c|c|c|c|c|}
\hline \multirow[b]{2}{*}{ IC variables } & \multirow{2}{*}{$\begin{array}{c}\text { Mean } \\
\text { difference }\end{array}$} & \multirow{2}{*}{$\begin{array}{l}\text { Std. error } \\
\text { difference }\end{array}$} & \multirow[b]{2}{*}{$T$} & \multirow[b]{2}{*}{ Sig. (two-tailed) } & \multicolumn{2}{|c|}{ 95\% confidence interval } \\
\hline & & & & & Lower & Upper \\
\hline $\mathrm{EICl}$ & -0.064 & 0.006 & -10.762 & 0.000 & -0.076 & -0.052 \\
\hline $\mathrm{EINCI}$ & 0.161 & 0.008 & 20.364 & 0.000 & 0.145 & 0.176 \\
\hline EEXCI & -0.270 & 0.012 & -22.756 & 0.000 & -0.293 & -0.246 \\
\hline EHUCl & -0.118 & 0.007 & -16.856 & 0.000 & -0.132 & -0.105 \\
\hline
\end{tabular}

Notes: Grouping variable: Group 1: Years 2010, 2011 and 2012; Group 2: Years, 2016, 2017 and 2018 
statistics results in Tables $\mathrm{V}$ and $\mathrm{VI}$ that disclosure of IC information has significantly increased from 2010 to 2018, except for EINCI.

Furthermore, regression analyses were conducted based on the two periods of the study's sample. Tables VIII and IX present the regression results of the relationship between extent of IC information and firms' market value. Table VIII shows the results for the first period (i.e. 2010-2012) which indicates that there is a significant positive impact of IC information on the market value of the listed companies. This finding supports the main findings for the panel data (pooled data for the two periods). Nevertheless, the disclosures of internal, external and human capital information are not statistically significant. On the contrary, Table IX shows the regression analysis of the relationship for the second period (i.e. 20162018). The results indicate that the extent of overall IC, INC, external capital and human capital information positively affects the market value of listed companies, which support the main findings of the study for the pooled data. This is a useful finding as it reveals that in the earlier period, only the aggregate of all IC components, i.e. overall $\mathrm{EICl}$ was value relevant. However, in the later period, each component of $\mathrm{IC}$ is being valued as relevant to investors by the market. Thus, Qatari companies that plan to enhance their firm value cannot neglect any of the components of IC, including INC.

\section{Table VIII Regression results of the effects of ICI on the FMV (2010-2012)}

\begin{tabular}{|c|c|c|c|c|c|}
\hline \multirow[b]{2}{*}{ Variables } & \multicolumn{2}{|c|}{ Unstandardised coefficients } & \multirow[b]{2}{*}{ Standardised coefficients B } & \multirow[b]{2}{*}{$\mathrm{T}$} & \multirow[b]{2}{*}{ Sig. } \\
\hline & B & Std. error & & & \\
\hline (Constant) & 0.059 & 0.147 & & 0.400 & 0.690 \\
\hline $\mathrm{EICl}$ & 0.142 & 0.306 & 0.009 & 0.463 & $0.044^{*}$ \\
\hline $\mathrm{EINCI}$ & 0.311 & 0.300 & 0.023 & 1.039 & 0.301 \\
\hline EEXCl & 0.133 & 0.171 & 0.017 & 0.775 & 0.440 \\
\hline $\mathrm{EHUCl}$ & 0.542 & 0.435 & 0.024 & 1.247 & 0.215 \\
\hline BVPS & 0.224 & 0.075 & 0.224 & 2.981 & $0.004^{* *}$ \\
\hline NETPROFT & 0.663 & 0.079 & 0.663 & 8.396 & $0.000^{* *}$ \\
\hline SIZE & 0.070 & 0.037 & 0.070 & 1.866 & 0.065 \\
\hline LEVERAGE & 0.046 & 0.045 & 0.046 & 1.013 & 0.313 \\
\hline DPS & 0.011 & 0.020 & 0.010 & 0.539 & 0.591 \\
\hline YEAR & -0.010 & 0.023 & -0.009 & -0.452 & 0.652 \\
\hline
\end{tabular}

Notes: $F=36.677$, Sig. $=0.000$, Adj. $R^{2}=0.657,{ }^{* *}$ Significant at the 0.01 level; ${ }^{*}$ Significant at the 0.05 level

Table IX Regression results of the effects of ICI on the FMV (2016-2018)

\begin{tabular}{lrrrrl}
\multicolumn{7}{c}{ Variables } & Unstandardised coefficients & & \\
& $B$ & Std. error & Standardised coefficients B & $T$ & Sig. \\
\hline (Constant) & 2.050 & 0.911 & & 2.252 & 0.026 \\
EICI & 72.588 & 26.474 & 2.229 & 2.742 & $0.007^{* *}$ \\
EINCI & 24.742 & 9.479 & 1.281 & 2.610 & $0.010^{* *}$ \\
EEXCI & 24.268 & 8.097 & 1.182 & 2.997 & $0.003^{* *}$ \\
EHUCI & 26.163 & 9.223 & 1.778 & 2.837 & $0.005^{* *}$ \\
BVPS & -0.130 & 0.073 & -0.130 & -1.785 & 0.077 \\
NETPROFT & 0.858 & 0.072 & 0.858 & 11.857 & $0.000^{* *}$ \\
SIZE & 0.006 & 0.065 & 0.006 & 0.087 & 0.931 \\
LEVERAGE & 0.012 & 0.054 & 0.012 & 0.226 & 0.821 \\
DPS & 0.003 & 0.078 & 0.003 & 0.039 & 0.969 \\
YEAR & -0.079 & 0.063 & -0.066 & -1.248 & 0.215 \\
Notes: $F=29.440$, Sig. $=0.000$, Adj. $R^{2}=0.695,{ }^{* *}$ Significant at the 0.01 level & &
\end{tabular}




\section{Conclusion}

This study examines the relationship between IC information disclosure and market value of the listed companies in QSE. It tests if the IC information affects the market value of the Qatari listed companies. The correlation and regression analyses show that there is a significant positive relationship between IC information and market value during the sample period. This finding indicates that IC information disclosed in the annual reports of the listed companies' impact their market values. The findings of the study have some implications on the body of knowledge, practice and policy making. First, the findings add to the current literature on the impact of IC information on the firms' market value in an emerging economy, especially in the GCC countries. This supports the prior studies that found a significant positive relationship, hence reduces the mixed findings of previous literature. Second, the findings of the paper have practical implications for companies, shareholders and investors. The Qatari listed companies will realise the importance of IC information disclosure and how such disclosure positively affects their market values. The shareholders and investors will use this information in the evaluation of a firm's market value. Third, the policy making implications of the findings are for authorities to ensure the implementation of the transformation to a KBE by the capital market and companies. With the shift to a KBE, knowledge is a driver for economic growth and has become more important than capital, land and labour. This shift makes the IC vital for companies to create wealth, value and gain competitive advantage. This has put pressure on companies to depend more on IC. The findings of the study show that the Qatari listed companies have started to depend more on $I C$, hence in line with the transformation towards a KBE.

Future studies are encouraged to examine the relationship with more variables. Qatar is an aggressively developing country, meaning that the results of this study could change if it were to consider other financial, economic and culture factors. This study may motivate other researchers to develop and use other methods that suit the unique characteristics of the Qatari market to explore the relationship between IC information and market value further.

\section{References}

Abdolmohammadi, M.J. (2005), "Intellectual capital disclosure and market capitalization", Journal of Intellectual Capital, Vol. 6 No. 3, pp. 397-416.

Abeysekera, I. (2011), "The relation of intellectual capital disclosure strategies and market value in two political settings", Journal of Intellectual Capital, Vol. 12 No. 2, pp. 319-338.

Abeysekera, I. and Guthrie, J. (2004), "Human capital reporting in a developing nation", The British Accounting Review, Vol. 36 No. 3, pp. 251-268.

Abeysekera, I. and Guthrie, J. (2005), "An empirical investigation of annual reporting trends of intellectual capital in Sri Lanka", Critical Perspectives on Accounting, Vol. 16 No. 3, pp. 151-163.

Abu Ghaida, R., Ousama, A.A., Hammami, H. and Shreim, O. (2016), "Do users in Qatar perceive intellectual capital information to be value relevant for decision-making purposes?", International Journal of Knowledge Management Studies, Vol. 7 Nos 1/2, pp. 36-52.

Alfraih, M.M. (2017), "The value relevance of intellectual capital disclosure: empirical evidence from Kuwait", Journal of Financial Regulation and Compliance, Vol. 25 No. 1, pp. 22-38.

Bornemann, M., Knapp, A., Schneider, U. and Sixl, K. (1999), "Holistic measurement of intellectual capital", International Symposium on Measuring and Reporting Intellectual Capital: Experience, Issue, and Prospects, 9-11 June, Amsterdam.

Bozzolan, S., Favotto, F. and Ricceri, F. (2003), "Italian annual intellectual capital disclosure: an empirical analysis", Journal of Intellectual Capital, Vol. 4 No. 4, pp. 543-558.

Bruggen, A., Vergauwen, P. and Dao, M. (2009), "Determinants of intellectual capital disclosure: evidence from Australia", Management Decision, Vol. 47 No. 2, pp. 233-245. 
Clarkson, P.M., Dontoh, A., Richardson, G. and Sefcik, S.E. (1992), "The voluntary inclusion of earnings forecasts in IPO prospectuses”, Contemporary Accounting Research, Vol. 8 No. 2, pp. 601-616.

Cormier, D., Ledoux, M.J. and Magnan, M. (2011), "The informational contribution of social and environmental disclosures for investors”, Management Decision, Vol. 49 No. 8, pp. 1276-1304.

Dashti, J., Aleemi, A.R. and Tariq, M. (2016), "Effects of intellectual capital information disclosure on market capitalization: evidence from Pakistan", City University Research Journal, Vol. 6 No. 1, pp. 191-203.

Drucker, P.F. (1992), The Age of Discontinuity: Guidelines to Our Changing Society, 2nd ed., Transaction Publishers, New Brunswick, NJ.

Ellis, H. and Seng, D. (2015), "The value relevance of voluntary intellectual capital disclosure: new Zealand evidence”, Corporate Ownership \& Control, Vol. 13 No. 1, pp. 1071-1087.

Ferraro, O. and Veltri, S. (2011), "The value relevance of intellectual Capital on the firm's market value: an empirical study on the Italian listed companies", International Journal of Knowledge-Based Development, Vol. 2 No. 1, pp. 66-84.

Gamerschlag, R. (2013), "Value relevance of human capital information", Journal of Intellectual Capital, Vol. 14 No. 2, pp. 325-345.

García-Meca, E. (2005), "Bridging the gap between disclosure and use of intellectual capital information", Journal of Intellectual Capital, Vol. 6 No. 3, pp. 427 -440.

García-Meca, E. and Martínez, I. (2005), "Assessing the quality of disclosure on intangibles in the Spanish Capital market”, European Business Review, Vol. 17 No. 4, pp. 305-313.

García-Meca, E. and Martínez, I. (2007), "The use of intellectual capital information in investment decisions: an empirical study using analyst reports", The International Journal of Accounting, Vol. 42 No. 1, pp. 57-81.

Gordon, L.A., Loeb, M.P. and Sohail, T. (2010), "Market value of voluntary disclosure concerning information security", MIS Quarterly, Vol. 34 No. 3, pp. 567-597.

Huang, C.C., Lurther, R., Tayles, M. and Haniffa, R. (2013), "Human Capital disclosure in developing countries: figureheads and value creators", Journal of Applied Accounting Research, Vol. 14 No. 2, pp. 180-196.

Ibrahim, M.K., Raudah, D., Haslinda, Y. and Normahiran, Y. (2004), "Market value and balance sheet numbers: evidence from Malaysia", in Khairul, A.K., Ibrahim, M.K. and Mohamed Zain, M. (Eds), Financial Reporting in Malaysia: Some Empirical Evidence, 1st ed., Utusan Publications \& Distributors Sdn Bhd, Kuala Lumpur.

International Monterey Fund - IMF (2016), World Economic Outlook: June 2016, International Monterey Fund.

Ittner, C.D., Larcker, D.F. and Randall, T. (2003), "Performance implications of strategic performance measurement in financial services firms", Accounting, Organizations and Society, Vol. 28 Nos 7/8, pp. 715-741.

Jog, V. and McConomy, B.J. (2003), "Voluntary disclosure of management earnings forecasts in IPO prospectuses", Journal of Business Finance Accounting, Vol. 30 Nos 1/2, pp. 125-168.

Kaplan, R.S. and Norton, D.P. (2001), "Transforming the balanced scorecard from performance measurement to strategic management”, Accounting Horizons, Vol. 15 No. 1, pp. 87-104.

Kennerley, M., Neely, A. and Adams, C. (2003), "Survival of the fittest: measuring performance in a changing business environment", Measuring Business Excellence, Vol. 7 No. 4, pp. 37-43.

Lev, B. (1992), "Information disclosure strategy”, California Management Review, Vol. 34 No. 4, pp. 9-32.

Lev, B. (2001), Intangibles: Management, Measuring and Reporting, Brookings Institution Press, Washington, DC.

Maditinos, D., Chatzoudes, D., Tsairidis, C. and Theriou, G. (2011), "The impact of intellectual capital on firms' market value and financial performance”, Journal of Intellectual Capital, Vol. 12 No. 1, pp. 132-151.

Mavrinac, S. and Siesfeld, A. (1997), "Measures that matter, an exploratory investigation of investors information needs and value properties", Enterprise Value in the Knowledge Economy, OECD and Ernst \& Young Center for Business innovation, Cambridge, MA.

Miller, W. (1999), "Building the ultimate resource", Management Review, pp. 42-45.

Mouritsen, J., Bukh, P.N. and Marr, B. (2004), "Reporting on intellectual capital: why, what and how?", Measuring Business Excellence, Vol. 8 No. 1, pp. 46-54. 
Nimtrakoon, S. (2015), “The relationship between intellectual capital, firms' market value and financial performance: empirical evidence from the ASEAN", Journal of Intellectual Capital, Vol. 16 No. 3, pp. 587-618.

Ohlson, J. (1995), "Earning, book values and dividends in equity valuation", Contemporary Accounting Research, Vol. 11 No. 2, pp. 661-687.

Ousama, A.A. and Fatima, A.H. (2012), "Extent and trend of intellectual capital reporting in Malaysia: empirical evidence", International Journal of Managerial and Financial Accounting, Vol. 4 No. 2, pp. 159-176.

Ousama, A.A., Fatima, A.H. and Hafiz Majdi, A.R. (2011a), "Usefulness of intellectual capital information: prepares' and users' views”, Journal of Intellectual Capital, Vol. 12 No. 3, pp. 430-445.

Ousama, A.A., Fatima, A.A. and Hafiz-Majdi, A.R. (2011b), "Effects of intellectual capital information disclosed in annual reports on market capitalization: evidence from bursa Malaysia", Journal of Human Resource Costing \& Accounting, Vol. 15 No. 2, pp. 85-101.

Powell, W.W. and Snellman, K. (2004), "The knowledge economy", Annual Review of Sociology, Vol. 30 No. 1, pp. 199-220.

Qatar National Vision - QNV (2008), "Qatar national vision 2030. General secretariat for development planning", available at: www.planning.gov.qa (accessed 8 March 2015).

Qatar Stock Exchange - QSE (2013), "Qatar stock exchange annual report 2013”, available at: www.qe. com.qa/documents/20181/52353378-b62c-62cf-930a-ce298475142e (accessed 6 August 2017).

Qatar Stock Exchange - QSE (2019), "Listed securities", available at: www.qe.com.qa/financialstatements (accessed 1 June 2019).

Stewart, T.A. (2000), Intellectual Capital: The New Wealth of Organizations, Nicholas Brealey Publishing, London, (reprinted from first published in hardback, 1997).

Taliyang, S.M., Harun, R.J., Mustafa, N.H. and Mansor, M. (2014), "Intellectual capital disclosure and market capitalization", International Journal of Business and Social Science, Vol. 5 No. 10, pp. 96-102.

Uyar, A. and Kiliç, M. (2012), "Value relevance of voluntary disclosure: evidence from Turkish firms", Journal of Intellectual Capital, Vol. 13 No. 3, pp. 363-376.

Vafaei, A., Taylor, D. and Ahmed, K. (2011), "The value relevance of intellectual capital disclosures", Journal of Intellectual Capital, Vol. 12 No. 3, pp. 407-429.

Viedma Marti, J.M. (2007), "In search of an intellectual capital comprehensive theory", The Electronic Journal of Knowledge Management, Vol. 5 No. 2, pp. 245-256.

Wang, Q., Sharma, U. and Davey, H. (2016), "Intellectual capital disclosure by Chinese and Indian information technology companies: a comparative analysis", Journal of Intellectual Capital, Vol. 17 No. 3 , pp. 507-529

Whiting, R.H. and Miller, J.C. (2008), "Voluntary disclosure of intellectual capital in New Zealand annual reports and the 'hidden value'", Journal of Human Resource Costing \& Accounting, Vol. 12 No. 1, pp. 26-50.

\section{Corresponding author}

A.A. Ousama can be contacted at: osamaanam@gmail.com

For instructions on how to order reprints of this article, please visit our website: www.emeraldgrouppublishing.com/licensing/reprints.htm

Or contact us for further details: permissions@emeraldinsight.com 